\title{
Induction of G1 arrest and apoptosis by schisandrin C isolated from Schizandra chinensis Baill in human leukemia U937 cells
}

\author{
CHEOL PARK $^{1 *}$, YOUNG-WHAN CHOI ${ }^{* *}$, SOOK KYUNG HYUN ${ }^{1}$, HYUN JU KWON ${ }^{1,2,5}$, HYE JIN HWANG ${ }^{1,3}$, \\ GI-YOUNG KIM ${ }^{7}$, BYUNG TAE CHOI ${ }^{1,8}$, BYUNG-WOO KIM ${ }^{1,2,5}$, IL-WHAN CHOI ${ }^{9}$, \\ SUNG-KWON MOON ${ }^{10}$, WUN-JAE KIM ${ }^{11}$ and YUNG HYUN CHOI ${ }^{1,4,5}$
}

\begin{abstract}
${ }^{1}$ Blue-Bio Industry Regional Innovation Center, ${ }^{2}$ Department of Life Science and Biotechnology, College of Natural Sciences, ${ }^{3}$ Department of Food and Nutrition, College of Human Ecology, ${ }^{4}$ Department of Biochemistry, College of Oriental Medicine, ${ }^{5}$ Department of Biomaterial Control, Graduate School, Dongeui University, Busan 614-052; ${ }^{6}$ Department of Horticultural Bioscience, Pusan National University, Miryang 627-706; ${ }^{7}$ Faculty of Applied Marine Science, Cheju National University, Jeju 690-756; ${ }^{8}$ Division of Meridian and Structural Medicine, School of Oriental Medicine, Pusan National University, Busan 609-735; ${ }^{9}$ Department of Microbiology, Inje University College of Medicine, Busan 614-735; ${ }^{10}$ Department of Food and Biotechnology, Chungju National University, Chungju, Chungbuk 380-702; ${ }^{11}$ Department of Urology, Chungbuk National University College of Medicine, Cheongju 361-763, Korea
\end{abstract}

Received May 27, 2009; Accepted July 6, 2009

DOI: 10.3892/ijmm_00000258

\begin{abstract}
We isolated two phytochemical lignans, schisandrin and schisandrin C, from Schizandra chinensis Baill and investigated their anti-cancer effects in human leukemia U937 cells. Schisandrin C inhibited cell growth in a dosedependent manner, which was associated with the induction of G1 arrest of the cell cycle and apoptosis; schisandrin did not inhibit growth. Schisandrin C induced G1 arrest was correlated with down-regulation of cyclin D1, cyclin E, cyclindependent kinase (Cdk) 4 and E2Fs expression, inhibition of phosphorylation of retinoblastoma protein (pRB), and upregulation of the Cdk inhibitor p21(WAF1/CIP1). In addition, schisandrin C-induced apoptosis was associated with downregulation of expression of the anti-apoptotic proteins $\mathrm{Bcl}-2$ and $\mathrm{Bcl}-\mathrm{xL}$, proteolytic activation of caspase- 3 and -9 , and a concomitant degradation of poly(ADP-ribose) polymerase (PARP). Furthermore, schisandrin C-induced apoptosis was significantly inhibited by a caspase-3 specific inhibitor $\mathrm{z}-$ DEVD-fmk, indicating an important role for caspase- 3 in the schisandrin $\mathrm{C}$ mechanism. In summary, growth inhibition by schisandrin $\mathrm{C}$ is related to cell cycle arrest at $\mathrm{G} 1$ and induction of caspase-3-dependent apoptosis in U937 cells;
\end{abstract}

Correspondence to: Dr Yung Hyun Choi, Department of Biochemistry, Dongeui University College of Oriental Medicine, Busan 614-052, Korea

E-mail: choiyh@deu.ac.kr

${ }^{*}$ Contributed equally

Key words: schisandrin C, G1 arrest, apoptosis, U937 these findings suggest that schisandrin $\mathrm{C}$ may be a useful chemotherapeutic agent.

\section{Introduction}

The progression of the cell cycle in eukaryotic cells is regulated by sequential activation and inactivation of cell cycle regulators, including cyclins, cyclin-dependent kinases (Cdks) and Cdk inhibitors $(1,2)$. Early G1 phase is regulated by complexes of D-type cyclins and Cdk4/6, and the G1/S transition is controlled by a complex of cyclin E and Cdk2 (3). Cdk inhibitors, including p16, p21 and p27, play a key role in negative regulation of cell cycle progression by binding to Cyclin/Cdk complexes $(3,4)$. Furthermore, retinoblastoma protein $(\mathrm{pRB})$ is also important for cell cycle progression during the G1 to $S$ phase transition. Dephosphorylation of pRB inhibits cell cycle progression by interacting with transcription factors of the E2F family, whereas phosphorylation of $\mathrm{pRB}$ results in induction of cell cycle progression through the breaking of $\mathrm{pRb} / \mathrm{E} 2 \mathrm{~F}$ complexes (2-4).

Together with inhibition of cell cycle progression, cancer cells can be removed by apoptosis (programmed cell death). In general, depending on the cell type or trigger, apoptosis can be initiated in two ways: by an extrinsic (death receptormediated) pathway or by an intrinsic (mitochondrial-mediated) pathway. In the former, plasma membrane death receptors are involved and the apoptosis signal is provided by the interaction between the ligand and the death receptor. The intrinsic pathway can be triggered by changes in mitochondrial integrity by a broad range of physical and chemical stimuli (5-7). Apoptosis is controlled by several genes including caspases and proteins of the Bcl-2 family. In particular, caspases, a family of cystein-containing aspartate-specific proteases, are known to play key roles in the apoptotic machinery, including cleavage of poly(ADP-ribose) polymerase 
(PARP) (8-10). The Bcl-2 family of proteins also control apoptosis but by interactions between pro- and anti-apoptotic members. Anti-apoptotic proteins (such as Bcl-2 and Bcl-xL) promote cell survival, whereas pro-apoptotic proteins (such as Bax and Bad) induce apoptosis $(6,11,12)$. Accumulating data have shown that many chemopreventive and/or chemotherapeutic agents can cause cell cycle arrest and/or cell death via the induction of apoptosis, which are the preferred methods of managing cancer. Therefore, the induction of cell cycle arrest and/or apoptotic cell death are important mechanisms in the anti-cancer properties of many drugs $(5,13)$.

Since ancient times, Schizandra chinensis Baill, a member of the Magnoliaceae family, has been used as a traditional medicinal herb in Asian countries, and has been shown to exert a wide array of pharmacological and biological effects including anti-cancer effects $(14,15)$. The seeds and fruits of $S$. chinensis are enriched in lignans, and more than 40 lignans have been isolated from this plant (15-21). Some lignans have previously been reported to induce cell cycle arrest and apoptosis in human cancer cell lines including leukemia cells (22-26). However, the underlying molecular mechanisms for their putative therapeutic effects are not clear. As part of an ongoing study to isolate chemopreventive or therapeutic compounds from medicinal plants, we isolated several lignans from the fruit of $S$. chinensis and compared their anti-cancer properties. In the present study, we compared the anti-proliferative and pro-apoptotic activities of two lignans, schisandrin and schisandrin $\mathrm{C}$, as potential anticancer agents. To this end, we examined whether these lignans affected cell cycle progression and induced apoptosis in human leukemia U937 cells.

\section{Materials and methods}

Chemicals and antibodies. Fruits of S. chinensis were collected in September 2005 from Moonkyeng, Republic of Korea. A voucher specimen (accession number SCPNUNPRL-1) has been deposited in the Herbarium of Pusan National University. DAPI (4,6-Diamidino-2-phenyllindile), paraformaldehyde, 3-(4,5-Dimethyl-2-thiazolyl)-2,5diphenyl-2H-tetrazolium bromide (MTT) and ethidium bromide (EtBr) were purchased from Sigma-Aldrich (St. Louis, $\mathrm{MO})$. Caspase activity assay kits were obtained from R\&D systems (Minneapolis, MN). The caspase-3 specific inhibitor, z-DEVD-fmk, was purchased from Calbiochem (San Diego, CA). Antibodies against cyclin D1, cyclin E, Cdk2, Cdk2, Cdk6, p16, p21 and p27 were purchased from Cell Signaling Technology (Danvers, MA). Antibodies against p130, pRB, E2F-1, E2F-4, tumor necrosis factor-related apoptosisinducing ligand (TRAIL), death receptor 4 (DR4), DR5, Fas, Fas ligand (FasL), Bcl-2, Bcl-xL, Bax, Bad, Bid, caspase-3, -8, -9 and actin were obtained from Santa Cruz Biotechnology (Santa Cruz, CA). Horseradish peroxidase (HRP)-conjugated anti-mouse and anti-rabbit secondary antibodies were purchased from Amersham Corp (Arlington Heights, IL).

Isolation and structure elucidation of lignans. The dried fruits of $S$. chinensis $(2.5 \mathrm{~kg})$ were ground to a fine powder and were successively extracted at room temperature with $n$ hexane, EtOAc and $\mathrm{MeOH}$. The hexane extract (308 g) was evaporated in vacuo and chromatographed on a silica gel
(40 $\mu \mathrm{m}$, J.T. Baker, NJ) column $(70 \times 8.0 \mathrm{~cm})$ with a step gradient $0,5,10,20$ and $30 \%$ EtOAc in hexane (each $1 \mathrm{~L}$ ). Fraction $11(3,476 \mathrm{mg})$ was separated on a silica gel column $(100 \times 3.0 \mathrm{~cm})$ with $25 \%$ hexane in $\mathrm{CHCl}_{3}$ to give $5 \mathrm{sub}$ fractions. Fraction 11IA was further purified by column chromatography on silica gel eluting with $\mathrm{CHCl}_{3}$-acetone (19:1) to give gomisin N (774 mg). Fraction 8 (1.579 mg) was separated on a silica gel column $(100 \times 3.0 \mathrm{~cm})$ with $\mathrm{CH}_{2} \mathrm{Cl}_{2}$ to give schisandrin $\mathrm{C}(501 \mathrm{mg})$. Fractions 36,37 and 38 $(10,533 \mathrm{mg})$ were separated on a silica gel column $(100 \times 3.0 \mathrm{~cm})$ with $5 \% \mathrm{CH}_{2} \mathrm{Cl}_{2}$ in acetone to give schisandrin $(4,606 \mathrm{mg})$. Pure GA was identified by HPLC on a Phenomenex Luna C18 column (Phenomenex, 150x4.6 mm I.D.; $5 \mu \mathrm{m}$ particle size). The chemical structure of lignans was verified by LC-MS (Bruker BioApex FT mass spectrometer) and NMR analysis (Varian inova 500 spectrometer). Optical rotations were recorded on a JASCO DIP-370 digital polarimeter. IR spectra were recorded on an AATI Mattson Genesis Series FTIR. NMR spectra $\left({ }^{1} \mathrm{H},{ }^{13} \mathrm{C}\right)$ were recorded in $\mathrm{CDCl}_{3}$ on a Varian inova 500 spectrometer operating at $500 \mathrm{MHz}$ for ${ }^{1} \mathrm{H}$ and $125 \mathrm{MHz}$ for ${ }^{13} \mathrm{C}$, running gradients and using residual solvent peaks as internal references. Highresolution mass spectra were recorded on a Bruker BioApex FT mass spectrometer.

Cell culture and growth inhibition study. Human leukemia U937 cells were obtained from the American Type Culture Collection (Rockville, MD) and cultured in RPMI-1640 medium (Gibco BRL, Gaithersburg, MD) supplemented with $10 \%$ heat-inactivated fetal bovine serum (FBS, Gibco BRL), $2 \mathrm{mM}$ glutamine, $100 \mathrm{U} / \mathrm{ml}$ penicillin and $100 \mu \mathrm{g} / \mathrm{ml}$ streptomycin in a humidified environment with $5 \% \mathrm{CO}_{2}$ at $37^{\circ} \mathrm{C}$. The proliferation of cells was assessed using the MTT assay, which is based on the conversion of MTT to MTT-formazan by mitochondrial enzymes (27).

Nuclear staining with DAPI. For evidence of apoptosis, morphological changes of nuclei were visualized following DNA staining using the fluorescent dye DAPI. Cells were seeded at $5 \times 10^{4}$ cells $/ \mathrm{ml}$ in 6 -well plates and incubated with schisandrin or schisandrin C. After incubation for $48 \mathrm{~h}$, cells were fixed with $3.7 \%$ paraformaldehyde for $20 \mathrm{~min}$ at room temperature, and washed with PBS. Cells were then stained with $2.5 \mu \mathrm{g} / \mathrm{ml}$ DAPI solution for $10 \mathrm{~min}$ at room temperature. The cells were then washed twice with PBS and stained nuclei were observed using fluorescence microscopy (Carl Zeiss, Germany) (28).

DNA flow cytometric analysis. After treatment with schisandrin or schisandrin $\mathrm{C}$, cells were harvested, washed twice with ice-cold PBS, fixed with $75 \%$ ethanol at $4^{\circ} \mathrm{C}$ for $30 \mathrm{~min}$, and stained using a DNA staining kit (CycleTest Plus kit, BectonDickinson, San Jose, CA) with propidium iodide (PI). DNA content at sub-G1, G1, S and G2/M phases were then determined by flow cytometry (FACSCalibur) and analyzed by Cell Quest software (Becton-Dickinson).

Protein extraction and Western blot analysis. Treated cells were collected with ice-cold PBS, and immediately lysed with lysis buffer (20 mM sucrose, $1 \mathrm{mM}$ EDTA, $20 \mu \mathrm{M}$ Tris- 
$\mathrm{Cl}, \mathrm{pH} 7.2,1 \mathrm{mM}$ DTT, $10 \mathrm{mM} \mathrm{KCl}, 1.5 \mathrm{mM} \mathrm{MgCl}_{2}$, containing protease inhibitors $(5 \mu \mathrm{g} / \mathrm{ml}$ pepstatin A, $10 \mu \mathrm{g} / \mathrm{ml}$ leupeptin and $2 \mu \mathrm{g} / \mathrm{ml}$ aprotinin). Protein concentrations were determined using Bio-Rad protein assay kits (Bio-Rad, Hercules, CA). After normalization, total proteins were subjected to sodium dodecyl sulfate (SDS)-polyacrylamide gels and then transferred to a nitrocellulose membrane (Schleicher and Schuell, Keene, NH) by electroblotting. The membrane was blocked with 5\% skim milk, and incubated with the primary antibodies and HRP-conjugated anti-mouse and anti-rabbit secondary antibodies. The target proteins were visualized by an enhanced chemiluminescence (ECL, Thermo scientific, Rockford, IL) detection system.

DNA fragmentation assay. Cells were treated with lysis buffer (10 mM Tris-HCl pH 7.4, $150 \mathrm{mM} \mathrm{NaCl,} 5 \mathrm{mM}$ EDTA and $0.5 \%$ Triton X-100) for $30 \mathrm{~min}$ at room temperature. After centrifugation, the supernatant was treated with proteinase $\mathrm{K}$ (final concentration $=0.5 \mathrm{mg} / \mathrm{ml}$ ) for $3 \mathrm{~h}$ at $50^{\circ} \mathrm{C}$. DNA was extracted with a $25: 24: 1$ (v/v/v) equal volume of neutral phenol:chloroform:isoamyl alcohol (Sigma), and centrifuged at 1,000 rpm for $10 \mathrm{~min}$. The upper aqueous layer was combined with $5 \mathrm{M} \mathrm{NaCl}$ and isopropanol, and incubated at $-20^{\circ} \mathrm{C}$ for $6 \mathrm{~h}$. Following centrifugation for $15 \mathrm{~min}$ at $14,000 \mathrm{rpm}$, the DNA pellets were air-dried and dissolved in TE buffer (10 mM Tris- $\mathrm{HCl}$ and $1 \mathrm{mM}$ EDTA) with $300 \mu \mathrm{g} / \mathrm{ml}$ RNase A. DNA samples were finally separated on $1.5 \%$ agarose gels and observed using an ultraviolet light source after staining with EtBr.

Assay of caspase activity. The enzymatic activity of caspases that had been induced by schisandrin and schisandrin $\mathrm{C}$ was recorded using colorimetric assay kits based on the manufacturer's protocol (R\&D Systems, Minneapolis, MN). Briefly, cells were lysed in a lysis buffer for $30 \mathrm{~min}$ on an ice bath. The lysed cells were centrifuged at 14,000 rpm for $10 \mathrm{~min}$, and $100 \mu \mathrm{g}$ protein was incubated with $50 \mu \mathrm{l}$ of reaction buffer and $5 \mu \mathrm{l}$ of colorimetric tetrapeptides, Asp-Glu-Val-Asp (DEVD)-p-nitroanilide (pNA) for caspase-3, Ile-Glu-ThrAsp (IETD)-pNA for caspase- 8 and Leu-Glu-His-Asp (LEHD)-pNA for caspase-9, respectively, at $37^{\circ} \mathrm{C}$ for $2 \mathrm{~h}$. The optical density of the reaction mixture was measured by changes in absorbance at $405 \mathrm{~nm}$ using a VersaMax tunable microplate reader (Molecular Devices, Palo Alto, CA) (29).

Statistical analysis. The data are expressed as means \pm SD. Statistical comparisons were performed using one-way ANOVA followed by a Fisher's test. Significant differences between the groups were determined using an unpaired Student's t-test. A $\mathrm{p}<0.05$ was considered significant.

\section{Results}

Isolation schisandrin from S. chinensis. Schisandrin was obtained as colorless needles (from $\mathrm{MeOH}$ ), $\mathrm{C}_{24} \mathrm{H}_{32} \mathrm{O}_{7}$, and $[\alpha]^{27} 16.0^{\circ}\left(\mathrm{c}=1.0, \mathrm{CHCl}_{3}\right)$. The IR spectra displayed a band at 3,500, suggesting the presence of an alcohol and a band at 1,610 indicating an aromatic functionality. The ${ }^{13} \mathrm{C}-\mathrm{NMR}$ spectra showed 24 signals, including 12 carbons for two aromatic rings and four O-methyls at $\delta=60.6(\mathrm{x} 2), 61.0(\mathrm{x} 2)$
A

B
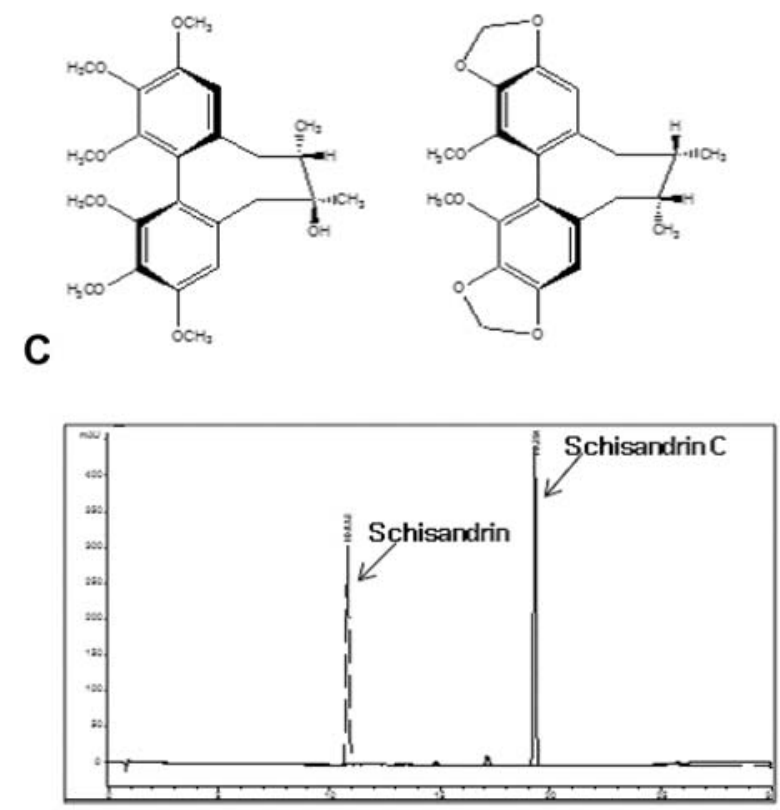

Figure 1. Chemical structures of schisandrin (A) and schisandrin C (B) isolated from $S$. chinensis Bail, and their HPLC profiles (C). HPLC analysis showed that the isolated lignans had a purity of more than $96 \%$.

and 55.9 (x2). It further showed the presence of two benzylic methylenes at $\delta=40.8$ and 34.2 , a tertiary carbon at $\delta=41.9$ and an oxygenated carbon at $\delta=77.4$ and two methyl carbons at $\delta=29.8$ and 15.8. The two aromatic protons of the biphenyl moiety resonated at $\delta=6.57$ (s) and 6.50 (s) for C-4 and C11 , respectively, and there were four methoxy groups at $\delta=$ $3.86(3 \mathrm{H} \times 2, \mathrm{~s}), 3.84(3 \mathrm{H} \times 2, \mathrm{~s})$ and $3.54(3 \mathrm{H} \mathrm{x} 2, \mathrm{~s})$. The three-proton doublet at $\delta=0.78(3 \mathrm{H}, \mathrm{d}, \mathrm{J}=7.5)$ and at $\delta=1.20$ $(3 \mathrm{H}, \mathrm{s})$ are indicative of the $\mathrm{C}-8$ and oxygenated $\mathrm{C}-7$ methyl group, respectively. A methine proton resonated at $\delta=1.83$ $(1 \mathrm{H}, \mathrm{m})$ (Fig. 1A). As shown in Fig. 1C, HPLC analysis showed that the isolated compound had a purity of more than $96 \%$.

Isolation of schisandrin C from S. chinensis. Schisandrin C was obtained as colorless needles (from $\mathrm{MeOH}$ ), $\mathrm{C}_{22} \mathrm{H}_{24} \mathrm{O}_{6}$, and $[\alpha]^{26}-36.8^{\circ}\left(\mathrm{c}=0.93, \mathrm{CHCl}_{3}\right)$. The IR spectra displayed a band at 1,610 indicating an aromatic moiety, and bands at 949 and 939 indicating a methylenedioxy functionality. The ${ }^{13} \mathrm{C}-\mathrm{NMR}$ and Dept spectra showed 22 signals, including 12 carbons for two aromatic rings, two methylenedioxy groups $(\delta=100.6 \times 2)$, and two O-methyls at $\delta=59.5(\mathrm{x} 2)$. It further showed the presence of two benzylic methylenes at $\delta=38.7$ and 35.2, two methine carbons at $\delta=33.5$ and 40.6 and two methyl carbons at $\delta=21.7$ and 12.5 . The two aromatic protons of the biphenyl moiety resonated at $\delta=6.479$ (s) and $6.475(\mathrm{~s})$, respectively and two methylenedioxy groups resonated at $5.94(2 \mathrm{H}, \mathrm{d})$ and $5.92(2 \mathrm{H}, \mathrm{d})$. The proton doublet at $\delta=0.96(3 \mathrm{H}, \mathrm{d}, \mathrm{J}=7.0)$ and at $\delta=0.76(3 \mathrm{H}, \mathrm{d}$, $\mathrm{J}=7.5$ ) are indicative of the $\mathrm{C}-8$ and $\mathrm{C}-7$ methyl group, respectively. The two methine groups at $\delta=1.86(1 \mathrm{H}, \mathrm{m})$ and 
A

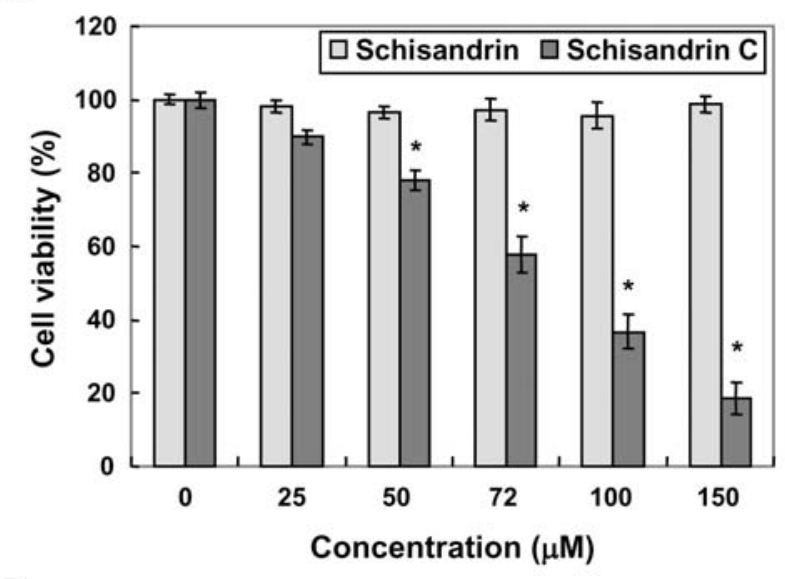

B

\begin{tabular}{cccc}
\hline \multirow{2}{*}{$\begin{array}{c}\text { Concentration } \\
(\mu \mathrm{M})\end{array}$} & \multicolumn{3}{c}{ Number of cells (\%) } \\
\cline { 2 - 4 } control & $\mathrm{G} 1$ & $\mathrm{~S}$ & $\mathrm{G} 2 / \mathrm{M}$ \\
\hline $\begin{array}{c}\text { Schisandrin } \\
25\end{array}$ & 54.91 & 24.02 & 21.07 \\
50 & 54.70 & 23.78 & 21.61 \\
100 & 55.76 & 23.24 & 21.00 \\
\hline Schisandrin C & & & \\
25 & 56.41 & 22.97 & 20.62 \\
50 & 57.89 & 21.50 & 20.64 \\
100 & 70.88 & 16.15 & 12.97 \\
\hline
\end{tabular}

Figure 2. Growth inhibition and G1 arrest of U937 cells by schisandrin C treatment. (A) U937 cells were plated at a density of $4 \times 10^{4}$ cells per $60-\mathrm{mm}$ plate, and then incubated for $24 \mathrm{~h}$. Next, the cells were treated with the indicated concentrations of schisandrin and schisandrin $\mathrm{C}$ for $48 \mathrm{~h}$ and cell viability was determined by MTT assay. Results are expressed as percentage of control $\pm \mathrm{SD}$ and represent the average of three separate experiments. Significance was determined by Student's t-test ( ${ }^{*} \mathrm{p}<0.05$ vs. untreated control). (B) Cells grown under the same conditions as (A) were collected, fixed, and stained with PI for flow cytometry analysis. The percentages of cells in each cell cycle phase are presented. The data represent the average of two independent experiments.

at $\delta=1.72(1 \mathrm{H}, \mathrm{m})$ are indicative of the $\mathrm{C}-8$ and $\mathrm{C}-7$ methyl groups, respectively (Fig. 1B). As shown in Fig. 1C, HPLC analysis showed that the isolated compound had a purity of more than $97 \%$.

Schisandrin C induction of growth inhibition and G1 arrest. In order to investigate whether schisandrin and schisandrin C inhibit cell growth, U937 cells were treated with various concentrations of schisandrin and schisandrin $\mathrm{C}$ for $48 \mathrm{~h}$ and the MTT assay was used to assess cell viability. As shown in Fig. 1A, treatment with schisandrin $\mathrm{C}$ decreased the viability of U937 cells in a concentration-dependent manner, whereas schisandrin did not inhibit the growth of U937 cells under the same conditions. To determine whether schisandrin $\mathrm{C}$ treatment of cells resulted in the alteration of cell cycle progression, the cell cycle patterns of the U937 cells were examined. The growth inhibiting action of schisandrin $\mathrm{C}$ was the consequence

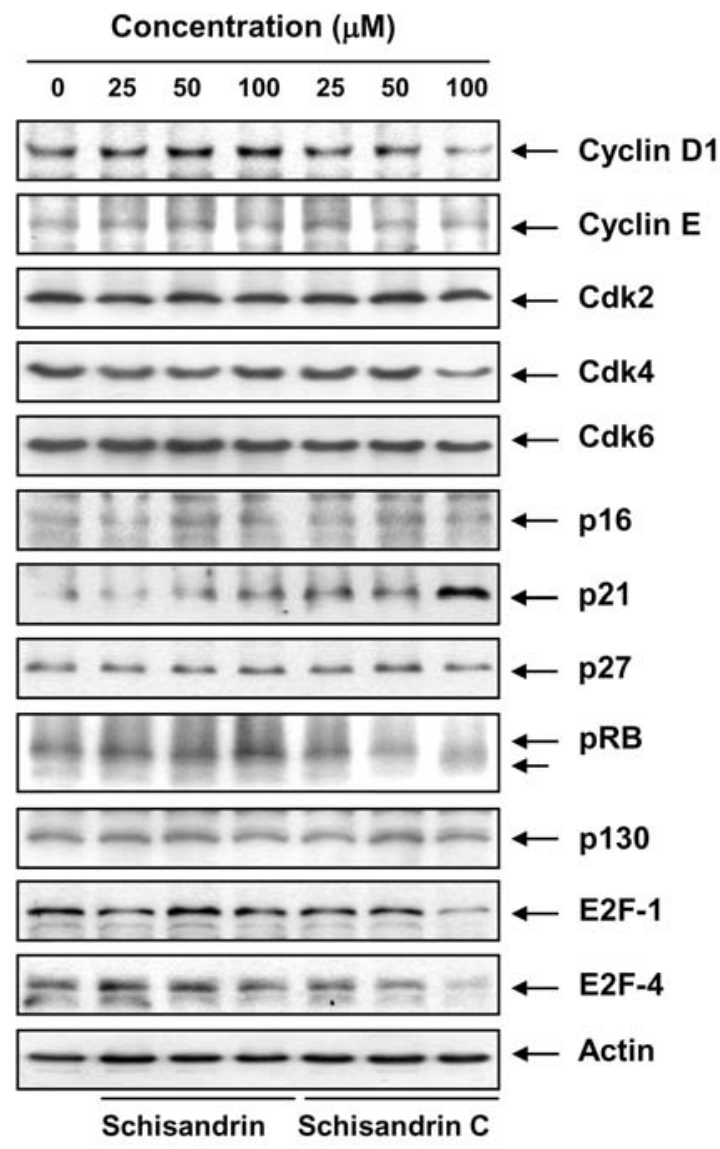

Figure 3. Effect of schisandrin and schisandrin $\mathrm{C}$ on the expression of cell cycle regulatory proteins in U937 cells. Cells were treated with the indicated concentrations of schisandrin and schisandrin C for $48 \mathrm{~h}$. Cells were lysed and proteins were separated by electrophoresis on SDS-polyacrylamide gels and transferred to nitrocellulose membranes. Next, the membranes were probed with the indicated antibodies and the proteins were visualized using an ECL detection system. Actin was used as an internal control.

of a G1 phase arrest (Fig. 2B). At a concentration of $100 \mu \mathrm{M}$, $70.88 \%$ of cells were in G1 phase and far fewer cells $(16.15$ and $13.97 \%$ ) were in $\mathrm{S}$ and $\mathrm{G} 2 / \mathrm{M}$ phases compared with the control. At the same concentration of schisandrin, there was no increase in the proportion of U937 cells in G1 phase. These results suggest that the growth inhibitory effect of schisandrin $\mathrm{C}$ in $\mathrm{U} 937$ cells is the result of G1 arrest.

Effects of schisandrin $C$ on the expression of cell cycleregulated proteins. To more clearly characterize the $\mathrm{G} 1$ phase arrest induced by schisandrin $\mathrm{C}$, we examined changes in the expression of proteins that have been known to control G1 cell cycle phase transitions in U937 cells. In comparison to control cells, cells treated with schisandrin $C$ exhibited a dosedependent decrease in the levels of cyclin D1, cyclin E and Cdk4 (Fig. 3), which is consistent with the role of these proteins in the regulation of the G1 to $S$ phase transition. Since the $R B$ gene product, $\mathrm{pRB}$, is also an important checkpoint protein in the $\mathrm{G} 1$ phase of the cell cycle, we next determined the kinetics between phosphorylation of $\mathrm{pRB}$ and the transcription factors, E2F-1 and E2F-4. Total levels of E2F-1 and E2F-4 were down-regulated and pRB expression, but not p130, decreased remarkably and changed from the hyper- 


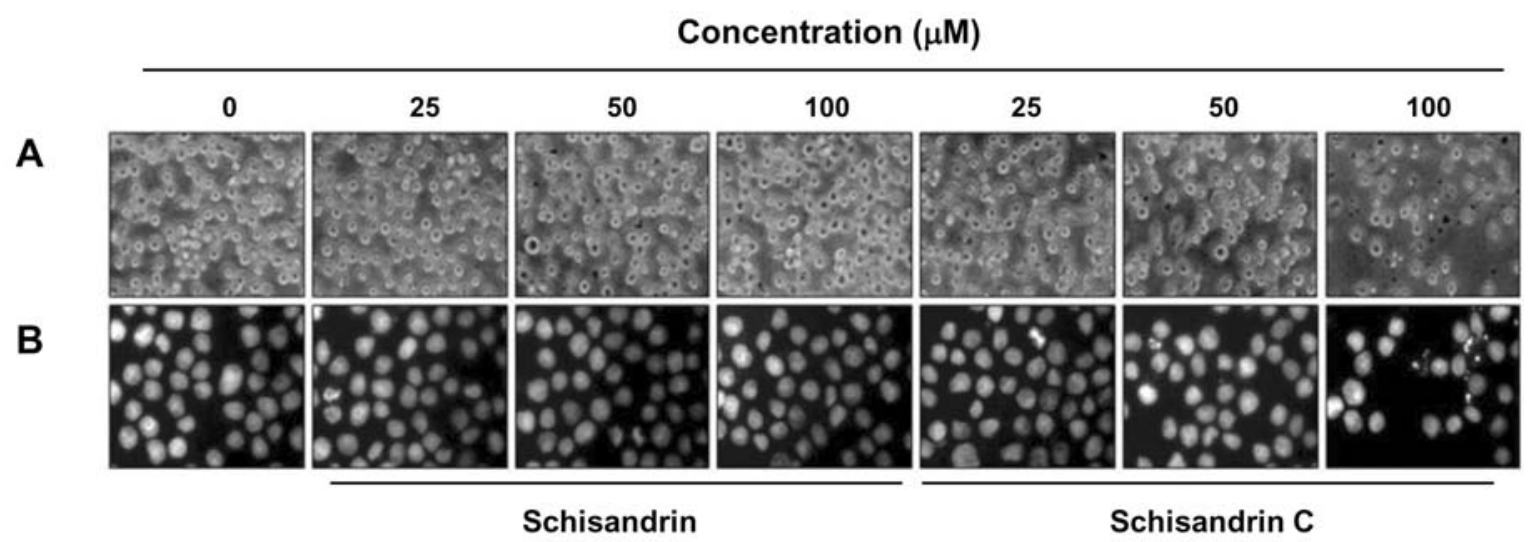

C

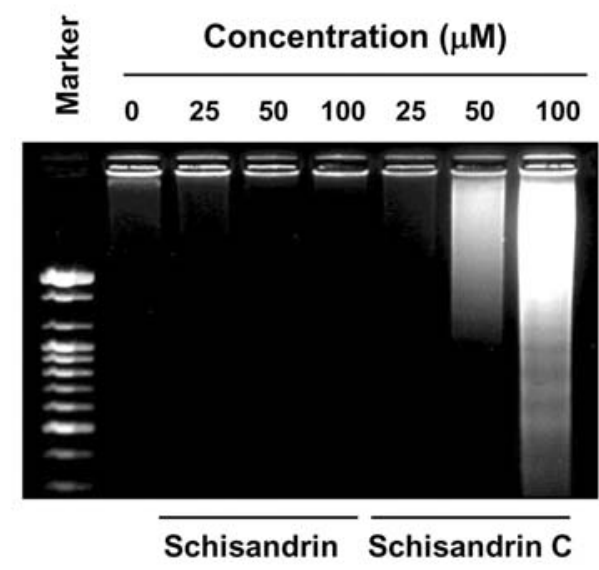

D

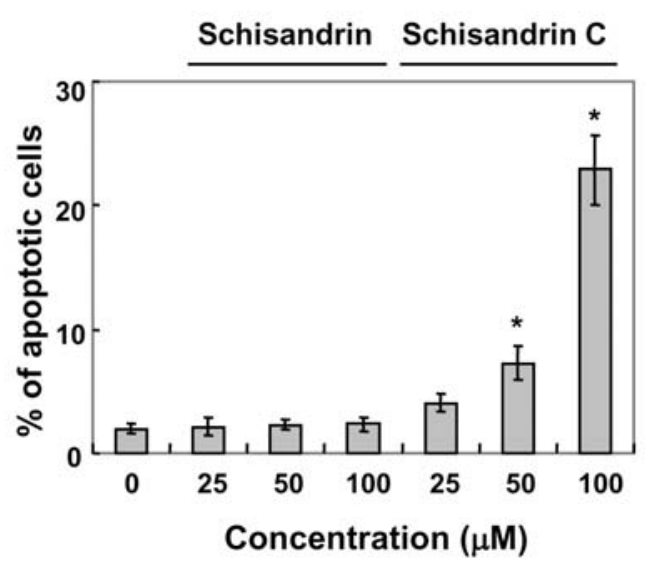

Figure 4. Schisandrin C treatment induces apoptosis in U937 cells. Cells were treated with the indicated concentrations of schisandrin and schisandrin C for $48 \mathrm{~h}$. (A) The cells were photographed by an inverted microscope (original magnification, x200). (B) Stained nuclei with DAPI solution were then photographed with a fluorescent microscope using a blue filter (original magnification, $\mathrm{x} 400$ ). Apoptotic cells (arrows). (C) To analyze fragmentation of genomic DNA, cells were treated for $48 \mathrm{~h}$ with the indicated concentrations of schisandrin and schisandrin C. DNA was extracted and analyzed by $1.5 \%$ agarose gel electrophoresis in the presence of EtBr. A representative result from two independent experiments is shown. (D) The presence of cells with subG1 DNA content following treatment with schisandrin and schisandrin C was evaluated using flow cytometry in order to quantify the onset of apoptosis. Each point represents the mean \pm SD of three independent experiments. Significance was determined by Student's t-test $\left({ }^{*} \mathrm{p}<0.05 \mathrm{vs}\right.$. untreated control).

phosphorylated form to the hypophosphorylated form after schisandrin $\mathrm{C}$ treatment. This effect of schisandrin $\mathrm{C}$ was dose-dependent. Furthermore, incubation of U937 cells with schisandrin $\mathrm{C}$ resulted in a concentration-dependent increase in expression of the Cdk inhibitor p21 (WAF1/CIP1) protein, whereas schisandrin $\mathrm{C}$ did not significantly affect expression levels of other Cdk inhibitors, including p16 and p27. Because the p53 gene is deleted in U937 cells (30), it is most likely that the induction of p21 is mediated in a p53-independent fashion. However, the expression of these proteins remained unchanged in schisandrin-treated U937 cells. These data suggest that schisandrin $\mathrm{C}$ induces $\mathrm{G} 1$ arrest via the modulation of cell cycle-regulating proteins.

Schisandrin C induces apoptosis in U937 cells. Further experiments were carried out to determine whether the growth inhibition and the G1 arrest induced by schisandrin C in U937 cells was closely associated with apoptotic cell death. Morphological analysis following DAPI staining was performed to analyze cells with nuclear chromatin condensation and apoptotic bodies. Under the inverted microscope, schisandrin C-treated cells exhibited a rounded and granulated morphology, and eventually degraded after treatment with $100 \mu \mathrm{M}$ schisandrin C (Fig. 4A). Moreover, cells treated with schisandrin $\mathrm{C}$ displayed chromosomal condensation and formation of apoptotic bodies (Fig. 4B). Schisandrin did not induce these morphological changes. We also analyzed whether DNA fragmentation, another hallmark of apoptosis, was induced by schisandrin C treatment of U937 cells. Following agarose gel electrophoresis of U937 cells treated with schisandrin $\mathrm{C}$ for $48 \mathrm{~h}$, but not schisandrin, a typical ladder pattern of internucleosomal fragmentation was observed in a concentration-dependent manner (Fig. 4C). We next analyzed the amount of sub-G1 DNA, which contains less DNA than cells in the G1 phase, to quantify the proportion of apoptotic cells. Flow cytometric analysis indicated that schisandrin $\mathrm{C}$ treatment resulted (in a concentration-dependent manner) in a markedly increased accumulation of cells in sub-G1 phase (Fig. 4D). These data suggest that the induction of $\mathrm{G} 1$ arrest by schisandrin $\mathrm{C}$ is closely associated with the induction of apoptosis in U937 cells.

Effects of schisandrin $C$ on the expression of apoptosisrelated proteins. Since the Fas/FasL system is a key signal 
A

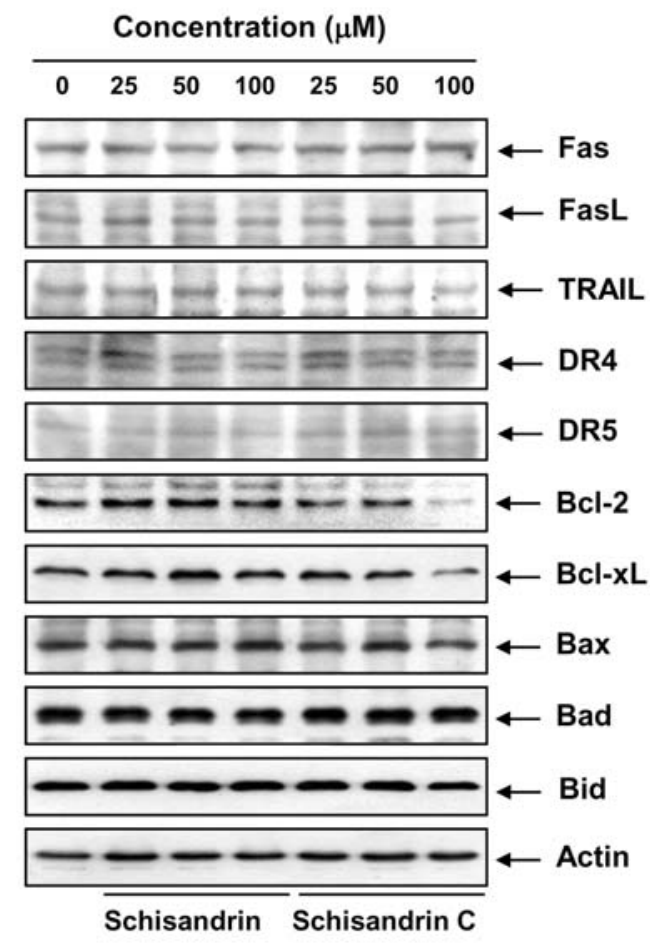

B
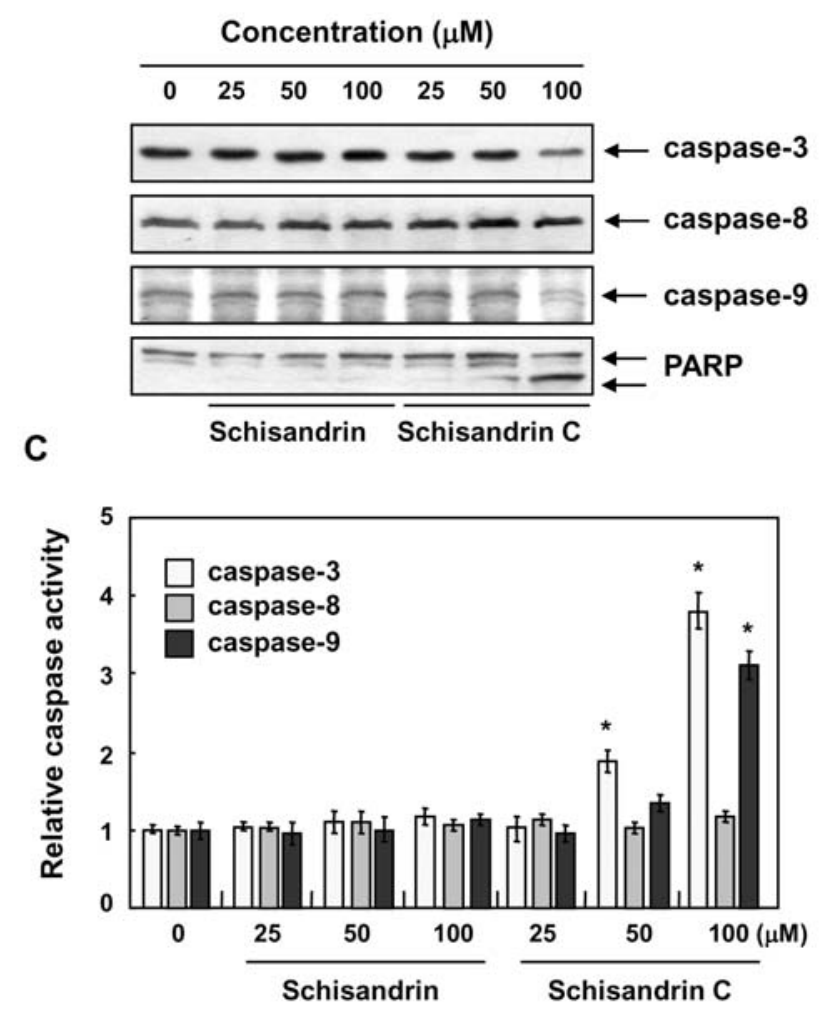

Figure 5. Schisandrin C treatment down-regulates expression levels of Bcl-2 and Bcl-xL and activates caspase-3 and -9 in U937 cells. (A and B) After a $48 \mathrm{~h}$ incubation with schisandrin and schisandrin $\mathrm{C}$, cells were lysed and cellular proteins were separated on SDS-polyacrylamide gels and transferred onto nitrocellulose membranes. The membranes were probed with the indicated antibodies. Proteins were visualized using the ECL detection system. Actin was used as a loading control. Representative results from two independent experiments are shown. (C) Cell lysates from cells grown under the same conditions were assayed for in vitro caspase-3, -8 , and -9 activity using DEVD-pNA, IETD-pNA and LEHD-pNA, respectively, as substrates at $37^{\circ} \mathrm{C}$ for 1 h. The released fluorescent products were measured. The data represent the mean \pm SD values of three independent experiments. Significance was determined by Student's t-test ( ${ }^{*} \mathrm{p}<0.05$ vs. untreated control).

transduction pathway for death receptor-mediated apoptosis, we examined the involvement of the Fas/FasL system in U937 cells treated with schisandrin C. As shown in Fig. 5A, neither the levels of Fas nor FasL expression were increased by schisandrin $\mathrm{C}$ treatment. Additionally, the levels of DR4, DR5 and TRAIL, other key molecules in the extrinsic pathway, were not induced after schisandrin $\mathrm{C}$ treatment. These data suggest that schisandrin $\mathrm{C}$ induced apoptosis does not occur via the receptor-mediated extrinsic pathway. To investigate a possible association with the mitochondria-mediated intrinsic pathway, we examined the expression levels of the Bcl-2 family of proteins directly interacting with the mitochondria. Western blot analyses revealed that the levels of Bax and Bad, two proapoptotic proteins, remained virtually unchanged in response to schisandrin $\mathrm{C}$, whereas the levels of Bcl-2 and Bcl-xL, two antiapoptotic proteins, were markedly inhibited by schisandrin $\mathrm{C}$ treatment (Fig. 5A). Under these conditions, the pro-apoptotic protein Bid, a BH3-only pro-apoptotic member of the Bcl-2 family, was not truncated and remained unchanged. These data indicate that the intrinsic pathway might be involved in schisandrin $\mathrm{C}$-induced apoptosis in U937 cells.

Activation of caspases by schisandrin $C$. To further investigate the apoptotic cascades involved in the effects of schisandrin C, U937 cells were exposed to schisandrin C and we measured expression levels of caspases $(-3,-8$ and -9$)$ and the in vitro activities of these proteins. As shown in Fig. 5B, schisandrin $\mathrm{C}$ treatment decreased the expression of pro-caspase- 3 and -9 proteins in a concentration-dependent manner. The expression levels of pro-caspase- 8 remained unchanged. To quantify the activities of caspase-3, -8 and -9 , lysates equalized for protein were obtained from cells treated with schisandrin $\mathrm{C}$ using DEVD-pNa, IETD-pNA and LEHD-pNA, respectively, as fluorogenic substrates. Schisandrin $\mathrm{C}$ treatment markedly activated caspase- 3 and -9 in a concentration-dependent manner; caspase- 8 was not activated (Fig. 5C). Furthermore, this compound induced a concomitant degradation of PARP, which is an endogenous substrate protein of caspase-3 (8), and cleavage fragments of these proteins were gradually increased in schisandrin $\mathrm{C}$ treated cells (Fig. 5B). These changes were not observed in schisandrin-treated U937 cells. In order to show that the activation of caspases is a key step in schisandrin $\mathrm{C}$-induced apoptosis, cells were pretreated with z-DEVD-fmk $(50 \mu \mathrm{M})$, a caspase-3 specific inhibitor, for $2 \mathrm{~h}$, followed by treatment with $100 \mu \mathrm{M}$ schisandrin $\mathrm{C}$ for $48 \mathrm{~h}$. As shown in Fig. 6A and B, pre-treatment with $\mathrm{z}-$ DEVD-fmk attenuated chromatin condensation and formation of apoptotic bodies, and restored cell viability. These results indicate that activation of caspases plays an important role in schisandrin C-induced apoptosis in U937 cells. 
A

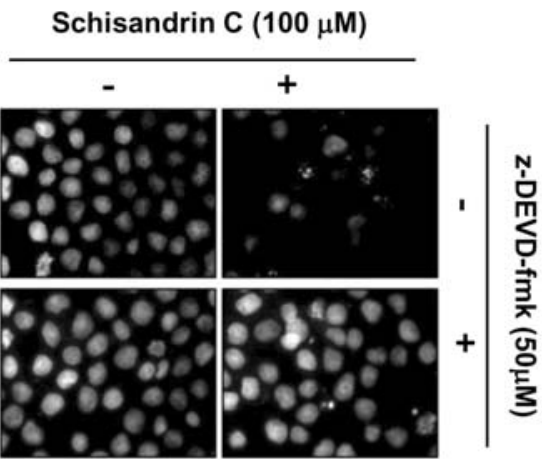

B

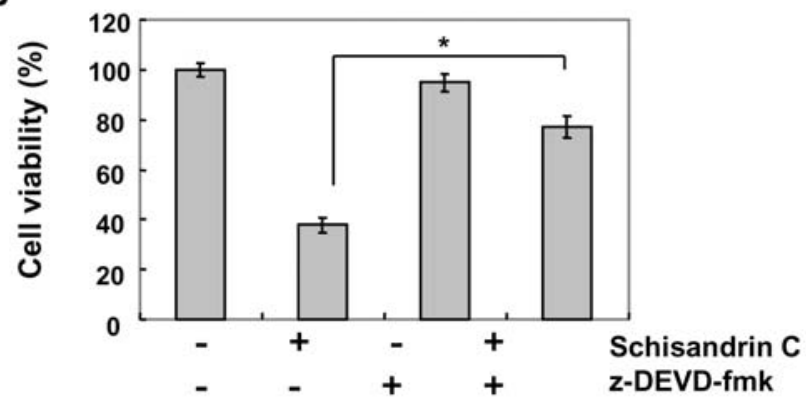

Figure 6. Inhibition of schisandrin C-induced apoptosis by a caspase-3 inhibitor in U937 cells. (A) Cells were treated with z-DEVD-fmk $(50 \mu \mathrm{M})$ for $1 \mathrm{~h}$ before a challenge with $100 \mu \mathrm{M}$ schisandrin $\mathrm{C}$ for $48 \mathrm{~h}$. The cells were stained with DAPI for $10 \mathrm{~min}$ and photographed with a fluorescent microscope using a blue filter (original magnification, x400). (B) In a parallel experiment, the degree of growth inhibition was determined by MTT assay. Each point represents the mean \pm SD of three independent experiments. Significance was determined by Student's t-test $\left(^{*} \mathrm{p}<0.05\right.$ vs. untreated control)

\section{Discussion}

The seeds and fruits of $S$. chinensis have a long history in Oriental medicine. The aim of treatment is to reduce cough, mouth dryness, spontaneous sweating, dysentery, insomnia and amnesia. More than 40 pharmacologically active lignans have been isolated from the fruit of $S$. chinensis (15-20). The major lignans in $S$. chinensis are schisandrin, schisandrin B, schisandrin $\mathrm{C}$, isoschizandrin, deoxyschisandrin, gomisin A, gomisin $\mathrm{N}$ and wuweizisu $\mathrm{C}$, and there have been shown to exert a wide array of pharmacological and biological activities including anti-cancer effects $(18,22-26,31)$. However, the precise mechanism of schisandrin $\mathrm{C}$-mediated cell growth inhibition is unclear. In the present study, we found that schisandrin $\mathrm{C}$ isolated from $S$. chinensis, but not schisandrin, causes G1 phase arrest and apoptosis in human leukemia U937 cells, which appeared to account for its anti-proliferative activity. Furthermore, the modulation of cell cycle regulators and apoptosis-related regulators was observed in the presence of schisandrin $\mathrm{C}$. These results provide the first evidence that schisandrin $\mathrm{C}$ induces abnormal cell cycle transitions that are associated with induction of apoptosis.

Progression from $\mathrm{G} 1$ to $\mathrm{S}$ phase of the cell cycle is regulated by D-type cyclins and cyclin $\mathrm{E}$, and their cognate kinases, Cdk2, Cdk4 and Cdk4, which act by phosphorylating and inactivating $\mathrm{pRB}$ prior to the restriction point at which cells commit to DNA synthesis, and by cyclin E-Cdk2, which acts later in $\mathrm{G} 1$ phase $(3,4)$. Therefore, any factor affecting the activity of these kinases could abrogate the normal inactivation of $\mathrm{pRB}$ and cause an accumulation of cells in $\mathrm{G} 1$ phase. Under normal conditions, pRB binds to the members of the E2F family of transcription factors. However, growth factors induce phosphorylation and dissociation of the pRB from E2F, which triggers G1 cell cycle progression $(1,3,4)$. Therefore, the complex between cyclin $\mathrm{D}$ or cyclin $\mathrm{E}$ and Cdks is an obvious candidate for control of pRB phosphorylation. If decreased levels of either protein or the association between respective binding partners were observed, a concomitant decrease in the degree of $\mathrm{pRB}$ phosphorylation would be expected (3-5). The data generated in this study demonstrate that in U937 cells, schisandrin C blocks pRB phosphorylation and decreases levels of E2F-1 and E2F-4. Furthermore, schisandrin $\mathrm{C}$ inhibits $\mathrm{Cdk} 4$ expression in association with enhanced expression of the Cdk inhibitor p21 (Fig. 3). Additionally, our data suggest that schisandrin Cinduced p21 upregulation involves a p53-independent pathway because U937 cells lack functional p53 (30).

Apoptosis is a process of gene-mediated programmed cell death essential for the elimination of unwanted cells in various biological systems and is the key mechanism of chemotherapeutic agents. Among the apoptosis-regulatory genes, the Bcl-2 family is a very important group of regulatory genes, either as inhibitors or as activators. The anti-apoptotic members, such as Bcl-2 and Bcl-xL, prevent loss of the mitochondrial membrane potential and, in particular, they have been reported to directly inhibit members of the caspase family, including caspase- 3 and $-9(6,11,12)$. Thus, it has been suggested that the ratio between the level of proapoptotic proteins such as Bax or Bad and levels of antiapoptotic factors determines whether a cell responds to an apoptotic signal $(11,12)$. In this study, the induction of apoptosis by schisandrin $\mathrm{C}$ was confirmed by characteristic morphological changes, DNA fragmentation and increases in the number of sub-G1 cells (Fig. 4). Furthermore, the data indicate that schisandrin $\mathrm{C}$ did not alter expression levels of Bax and Bad in U937 cells but did selectively down-regulate the expression of Bcl-2 and Bcl-xL without alteration of death-receptor related regulators, resulting in an increase in the ratio of Bax and Bad/Bcl-2 and Bcl-xL (Fig. 5).

Execution of cellular demolition by apoptosis is also carried out by caspases $(6,10)$. The caspases are a family of proteins that are one of the main executors of the apoptotic process. They belong to a group of enzymes known as cysteine proteases and exist within the cell as inactive pro-forms or zymogens. These zymogens can be cleaved to form active enzymes following the induction of apoptosis. Caspase signaling is initiated and propagated by proteolytic autocatalysis, as well as the cleavage of downstream caspases and substrates $(9,10)$. In addition, caspase- 3 is known to be one of the key executioners of apoptosis. This is because it is either partially or totally responsible for the proteolytic cleavage of many key proteins such as PARP, which is important for cell viability, but also serves as a marker of apoptosis when cleaved (8). Further studies have shown that exposure of U937 cells to schisandrin C causes a proteolytic activation of caspase- 9 as well as caspase- 3 in a dosedependent manner and the concomitant degradation of 
PARP, again correlating with an activation of caspases during apoptosis by schisandrin C (Fig. 5). Specifically, we found that treatment with schisandrin $\mathrm{C}$ in the presence of a caspase- 3 inhibitor prevented apoptosis and growth inhibition, suggesting that schisandrin $\mathrm{C}$-induced apoptosis is caused by caspase-3-dependent cell death, and that caspase-3 plays an important role in schisandrin C-induced apoptosis in U937 cells (Fig. 6). The present results indicate that schisandrin $\mathrm{C}$ increases the activation of caspase-9, leading to the activation of caspase-3, which, in turn, results in PARP degradation.

In this study, we have suggested a mechanism by which schisandrin C induces inhibition of human leukemia U937 cell growth, G1 arrest and apoptosis induction. The G1 arrest induced by schisandrin $\mathrm{C}$ is associated with the up-regulation of p21 and the down-regulation of cyclin D1, Cdk4, pRB and E2Fs. The apoptotic events induced by schisandrin $C$ are mediated by inhibition of the expression of anti-apoptotic proteins $\mathrm{Bcl}-2$ and $\mathrm{Bcl}-\mathrm{xL}$ and activation of caspases. Therefore, we believe that schisandrin $\mathrm{C}$ is a promising candidate for cancer chemoprevention and/or chemotherapy. Further efforts to explore this agent are now necessary.

\section{Acknowledgements}

This study was supported by Blue-Bio Industry RIC at DongEui University as a RIC (08-06-07) program of ITEP under Ministry of Knowledge Economy and the Korea Science and Engineering Foundation (KOSEF) grant funded by the Korea government (MEST) (PT-ERC, R11-2008-014-00001-0).

\section{References}

1. Sherr CJ: Cancer cell cycles. Science 274: 1672-1677, 1996.

2. Kastan MB and Bartek J: Cell-cycle checkpoints and cancer. Nature 432: 316-323, 2004

3. Sherr CJ and Roberts JM: Inhibitors of mammalian G1 cyclindependent kinases. Genes Dev 9: 1149-1163, 1995.

4. Weinberg RA: The retinoblastoma protein and cell cycle control. Cell 81: 323-330, 1995.

5. Meiler J and Schuler M: Therapeutic targeting of apoptotic pathways in cancer. Curr Drug Targets 7: 1361-1369, 2006.

6. Jeong SY and Seol DW: The role of mitochondria in apoptosis. BMB Rep 41: 11-22, 2008.

7. Degterev A and Yuan J: Expansion and evolution of cell death programmes. Nat Rev Mol Cell Biol 9: 378-390, 2008.

8. Lazebnik YA, Kaufmann SH, Desnoyers S, Poirier GG and Earnshaw WC: Cleavage of poly(ADP-ribose) polymerase by a proteinase with properties like ICE. Nature 371: 346-347, 1994.

9. Earnshaw WC, Martins LM and Kaufmann SH: Mammalian caspases: structure, activation, substrates and functions during apoptosis. Annu Rev Biochem 68: 383-424, 1999

10. Stennicke HR and Salvesen GS: Properties of the caspases Biochim Biophys Acta 1387: 17-31, 1998.

11. Allen RT, Cluck MW and Agrawal DK: Mechanisms controlling cellular suicide: role of Bcl-2 and caspases. Cell Mol Life Sci 54: 427-445, 1998.

12. Burlacu A: Regulation of apoptosis by Bcl-2 family proteins. J Cell Mol Med 7: 249-257, 2003.

13. Khan N, Adhami VM and Mukhtar H: Apoptosis by dietary agents for prevention and treatment of cancer. Biochem Pharmacol 76: 1333-1339, 2008.
14. Liu GT: Pharmacological actions and clinical use of Fructus schizandrae. Chin Med J 102: 740-749, 1989.

15. Panossian A and Wikman G: Pharmacology of Schisandra chinensis Bail.: an overview of Russian research and uses in medicine. J Ethnopharmacol 118: 183-212, 2008.

16. Ikeya Y, Taguchi H, Yosioka I and Kobayashi H: The constituents of Schizandra chinensis Baill. I. Isolation and structure determination of five new lignans, gomisin A, B, C, F and G, and the absolute structure of schizandrin. Chem Pharm Bull 27: 1383-1394, 1979.

17. Lee YW, Voyksner RD, Pack TW, Cook CE, Fang QC and Ito Y: Application of countercurrent chromatography/thermospray mass spectrometry for the identification of bioactive lignans from plant natural products. Anal Chem 62: 244-248, 1990.

18. Slanina J, Táborská E and Lojková L: Lignans in the seeds and fruits of Schisandra chinensis cultured in Europe. Planta Med 63: 277-280, 1997.

19. Huang X, Song F, Liu Z and Liu S: Studies on lignan constituents from Schisandra chinensis (Turcz.) Baill. fruits using highperformance liquid chromatography/electrospray ionization multiple-stage tandem mass spectrometry. J Mass Spectrom 42: 1148-1161,2007.

20. Lu Y and Chen DF: Analysis of Schisandra chinensis and Schisandra sphenanthera. J Chromatogr A 1216: 1980-1990, 2009.

21. Cho JY, Kim AR, Yoo ES, Baik KU and Park MH: Immunomodulatory effect of arctigenin, a lignan compound, on tumour necrosis factor- $\alpha$ and nitric oxide production, and lymphocyte proliferation. J Pharm Pharmacol 51: 1267-1273, 1999.

22. Hausott B, Greger H and Marian B: Naturally occurring lignans efficiently induce apoptosis in colorectal tumor cells. J Cancer Res Clin Oncol 129: 569-576, 2003.

23. Matsumoto T, Hosono-Nishiyama K and Yamada H: Antiproliferative and apoptotic effects of butyrolactone lignans from Arctium lappa on leukemic cells. Planta Med 72: 276-278, 2006.

24. Lin S, Fujii M and Hou DX: Molecular mechanism of apoptosis induced by schizandrae-derived lignans in human leukemia HL-60 cells. Food Chem Toxicol 46: 590-597, 2008.

25. Pan MH and Ho CT: Chemopreventive effects of natural dietary compounds on cancer development. Chem Soc Rev 37: 2558-2574, 2008

26. Min HY, Park EJ, Hong JY, Kang YJ, Kim SJ, Chung HJ, Woo ER, Hung TM, Youn UJ, Kim YS, Kang SS, Bae K and Lee SK: Antiproliferative effects of dibenzocyclooctadiene lignans isolated from Schisandra chinensis in human cancer cells. Bioorg Med Chem Lett 18: 523-526, 2008.

27. Dash R, Acharya C, Bindu PC and Kundu SC: Antioxidant potential of silk protein sericin against hydrogen peroxideinduced oxidative stress in skin fibroblasts. BMB Rep 41: 236-241, 2008.

28. Jung EJ, Kim CW and Kim DR: Cytosolic accumulation of gammaH2 $\mathrm{AX}$ is associated with tropomyosin-related kinase Ainduced cell death in U2OS cells. Exp Mol Med 40: 276-285, 2008.

29. Lee W, Choi HI, Kim MJ and Park SY: Depletion of mitochondrial DNA up-regulates the expression of MDR1 gene via an increase in mRNA stability. Exp Mol Med 40: 109-117, 2008.

30. Danova M, Giordano M, Mazzini G and Riccardi A: Expression of $\mathrm{p} 53$ protein during the cell cycle measured by flow cytometry in human leukemia. Leuk Res 14: 417-422, 1990.

31. Yasukawa K, Ikeya Y, Mitsuhashi H, Iwasaki M, Aburada M, Nakagawa S, Takeuchi $\mathrm{M}$ and Takido M: Gomisin A inhibits tumor promotion by 12-O-tetradecanoylphorbol-13-acetate in two-stage carcinogenesis in mouse skin. Oncology 49: 68-71, 1992. 